Volume 55, Issue 1 (Winter 2018)

The CJPTA: A Decade of Progress

Guest editors: Janet Walker, Gerard Kennedy, and Sagi

Peari

\title{
Three Objections to Forum of Necessity: Global Access to Justice, International Criminal Law, and Proper Party
}

Sagi Peari

Osgoode Hall Law School of York University

Follow this and additional works at: http://digitalcommons.osgoode.yorku.ca/ohlj

Part of the Law Commons

Article

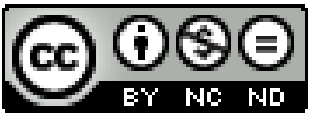

This work is licensed under a Creative Commons Attribution-Noncommercial-No Derivative Works 4.0 License.

\section{Citation Information}

Peari, Sagi. "Three Objections to Forum of Necessity: Global Access to Justice, International Criminal Law, and Proper Party." Osgoode Hall Law Journal 55.1 (2018) : 225-238.

http://digitalcommons.osgoode.yorku.ca/ohlj/vol55/iss1/7 


\title{
Three Objections to Forum of Necessity: Global Access to Justice, International Criminal Law, and Proper Party
}

\begin{abstract}
In civil procedure, the plaintiff is the one who initiates the litigation process. In which forum can he or she initiate this process? In very general terms, the Canadian rules of judicial jurisdiction provide the plaintiff with three options for jurisdiction acquisition. First, the jurisdiction can be acquired based on explicit agreement between the plaintiff and the defendant as to the identity of the forum to adjudicate the case. Second, the plaintiff can initiate the litigation in the forum that has the so-called "real and substantial connection" between it and the parties' specific interaction under the given ground of liability (i.e., tort, contract, and so on). Finally, the jurisdiction can be acquired in the forum of the present location of the defendant.
\end{abstract}

\section{Cover Page Footnote}

I am indebted to Professor Frederick Zemans for his helpful comments on issues discussed in this paper. 
Special Issue

The CJPTA: A Decade of Progress

\title{
Three Objections to Forum of Necessity: Global Access to Justice, International Criminal Law, and Proper Party
}

\author{
SAGI PEARI*
}

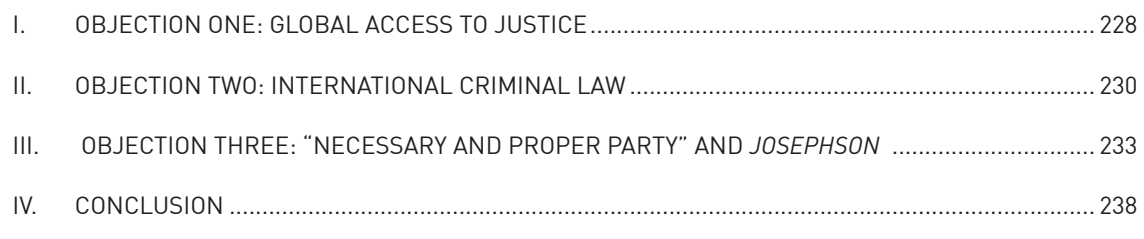

IN CIVIL PROCEDURE, THE PLAINTIFF is the one who initiates the litigation process. In which forum can he or she initiate this process? In very general terms, the Canadian rules of judicial jurisdiction provide the plaintiff with three options for jurisdiction acquisition. First, the jurisdiction can be acquired based on explicit agreement between the plaintiff and the defendant as to the identity of the forum to adjudicate the case. Second, the plaintiff can initiate the litigation in the forum that has the so-called "real and substantial connection" between it and the parties' specific interaction under the given ground of liability (i.e., tort, contract, and so on). Finally, the jurisdiction can be acquired in the forum of the present location of the defendant. ${ }^{1}$

* LLM, SJD (University of Toronto); Visiting Scholar and Adjunct Faculty, Osgoode Hall Law School. I am indebted to Professor Frederick Zemans for his helpful comments on issues discussed in this paper.

1. Club Resorts Ltd v Van Breda, 2012 SCC 17, [2012] 1 SCR 572 [Club Resorts]. 
Thus, for example in the case of a contract signed between an Ontario resident with a German resident, signed in Ontario with respect to delivery of goods in Brazil, the German resident has the option to sue the Ontario resident for breach of the contract in: an Ontario court (the place of contract formation and the present location of the Ontario resident at the time of contract formation under the "real and substantial connection" test); in Brazil (the place of contractual performance under the "real and substantial connection" test); New York (if that is the place of the Ontario resident's present permanent residence); or even in England (if the parties explicitly included in their agreement a so-called "jurisdiction clause" that in case of a dispute between them, the case will be adjudicated in an English court).

The doctrine of forum of necessity ("Necessity") offers the plaintiff a fourth option of jurisdiction acquisition. According to this option, none of the above grounds are required to establish jurisdiction: neither an explicit forum choice, nor a "real and substantial connection" with the forum, nor the present location of the defendant. Rather, Necessity provides the plaintiff with the option to acquire jurisdiction over the defendant based on certain circumstances related to the plaintiffs inability to acquire jurisdiction over the defendant elsewhere across the globe. In other words, Necessity grants the plaintiff the right to sue because of some objective obstacle the plaintiff would encounter elsewhere. Thus, for example, under Necessity, the Ontario court would consider a German plaintiffs claim with respect to a contract between her and a French resident for delivery of goods in Brazil. This is without a jurisdiction clause in their contract pointing to Ontario as the place for any future litigation, and without the parties or the cause of action (the contract) having any relation to Ontario. What would matter in this case are the obstacles that the German resident could have encountered in suing the French resident elsewhere in the world, specifically in such potentially relevant places for jurisdiction acquisition as: France, Germany, Brazil, or other jurisdictions based on the forum choice provision that the parties could have incorporated into their contract.

Canadian jurisprudence has generally been receptive of Necessity, viewing it as an independent, residual ground for judicial jurisdiction acquisition. Indeed, Necessity has been explicitly adopted in the provinces of British Columbia and Nova Scotia under the auspices of the Court Jurisdiction and Proceedings Transfer Act ("CJPTA"), ${ }^{2}$ it appears in article 3136 of the Civil Code of Québec, ${ }^{3}$ and seems

2. See Court Jurisdiction and Proceedings Transfer Act, SBC 2003, c 28, s 18(2)(b); Court Jurisdiction and Proceedings Transfer Act, SNS 2003, (2nd Sess), c 2, s 19(2)(b).

3. Art 3136 CCQ. 
to be destined in the future to be elaborated upon and developed by the Supreme Court of Canada, according to the Club Resorts case. ${ }^{4}$ Necessity appears to have received solid support from academic scholars in Canada, ${ }^{5}$ and appears well accepted within various systems around the world. ${ }^{6}$ While acknowledging the presently high threshold for the actual application of Necessity within Canadian courts, ${ }^{7}$ scholars have been clearly in favour of the doctrine and support its further development, extension, and expansion to a variety of cases. ${ }^{8}$ Necessity seems to be one of the future fundamental building blocks of Canadian judicial jurisdiction.

The following discussion aims to raise some serious concerns about the very plausibility of Necessity as a legitimate ground for jurisdiction acquisition. It raises challenges to the incorporation of Necessity within Canadian jurisprudence and, subsequently, raises concerns about the suggested extension and expansion of the doctrine. In this way, I applaud the province of Saskatchewan, which has chosen not to incorporate Necessity within its CJPTA adoption process. ${ }^{9}$ Briefly stated, the objections to Necessity (and its extension) can be structured around the following three interrelated lines. First, the adoption of Necessity means a mischaracterization of the nature and scope of the domestically developed principle of "access to justice." Second, Necessity challenges the division between private international law and international criminal law which de facto leads to the conceptual collapse of Necessity into the doctrine of "universal jurisdiction."

4. Club Resorts, supra note 1 at paras 59, 86.

5. See e.g. John McEvoy, "Forum of Necessity in Quebec Private International Law: C c Q art 3136” (2005) 35:1 RGD 61 at 111-12 (supporting further extension of Necessity in the context of financial difficulties of litigating parties); Vaughan Black, Stephen Pitel \& Michael Sobkin, Statutory Jurisdiction: An Analysis of the Court Jurisdiction and Proceedings Transfer Act (Toronto: Carswell, 2012) at 154-89 .

6. Chilenye Nwapi, "A Necessary Look at Necessity Jurisdiction” (2014) 47:1 UBC L Rev 211 at 213-27; Arnaud Nuyts, Study of Residual Jurisdiction: Review of the Member States' Rules concerning the "Residual Jurisdiction" of their courts in Civil and Commercial Matters pursuant to the Brussels I and II Regulations (Brussels: European Commission, 2007) at 83-86, online: $<$ ec.europa.eu/civiljustice/news/docs/study_residual_jurisdiction_en.pdf>.

7. Michael Sobkin, "Residual Discretion: The Concept of Forum of Necessity Under the Uniform Court Jurisdiction and Proceedings Transfer Act" (2018) 55:1 Osgoode Hall LJ 203 (mentioning "Canadian courts have so far viewed the threshold for assuming jurisdiction on the basis of forum of necessity as high" at 205).

8. Ibid at 215 (seemingly supporting a liberal interpretation of Necessity as referring to circumstances in which the plaintiff simply cannot "reasonably" acquire jurisdiction in a foreign system). Sobkin suggests extending Necessity to circumstances of the "necessary and proper party" (ibid at 215); to a "broader range of cases" (ibid at 213); and to cases of discrimination within a foreign system (ibid at 214).

9. On the reluctance of the province of Saskatchewan to adopt Necessity within its CJPTA adoption process, see Black, Pitel \& Sobkin, supra note 5 at 174-77. 
Third, in contrast to what one might argue, Necessity is not an appropriate vehicle for rehabilitation of the traditional jurisdictional doctrine of "proper and necessary party." The following sections elaborate on each one of the objections in turn.

\section{OBJECTION ONE: GLOBAL ACCESS TO JUSTICE}

The "access to justice" principle is a good place to start the journey towards making a case against Necessity. It is evident that the defenders of the doctrine have relied on this principle as an ultimate justification for its very existence and its future expansion. ${ }^{10}$ The greatest difficulty with this position lies in its underlying presumption that the domestically developed principle of "access to justice" can be easily extended to a global level. Indeed, "access to justice" is clearly central to Canadian jurisprudence. ${ }^{11}$ It signifies the justifiable desire to address some key shortcomings of the domestic dispute resolution system, such as shortages of judges, insufficient funding of legal aid for disadvantaged litigants, delays in dispute resolution, inadequate incorporation of Aboriginal law traditions, and other aspects of the domestic system that affect the litigating parties' ability to access it. ${ }^{12}$

One might, however, cast doubt on whether Necessity should be understood as global access to justice and challenge the very applicability of the "access to justice" principle to international private interactions. It is one thing to support access to justice within a domestic dispute resolution system and with respect to domestic litigants, but it is another thing altogether to open up Canadian courts to foreign litigants who have no connection, or only a very weak connection, to Canada.

Leaving aside constitutional challenges with respect to the nature and strength of the required connection between the litigating parties and the forum to meet the apparently constitutional grounds of the "real and substantial connection"

10. Sobkin, supra note 7 at 218 (describing circumstances where Necessity is the "only hope for access to justice" at 217). The author also explicitly links Necessity to "access to justice" and mentions that Necessity is "concerned with access to justice." See ibid at 222. See also McEvoy, supra note 5 at 111; Lamborghini (Canada) Inc v Automobile Lamborghini SPA, [1997] RJQ 58 at para 44, 68 ACWS (3d) 62 [Lamborghini].

11. See e.g. Hryniakv Mauldin, 2014 SCC 7 at para 1, [2014] 1 SCR 87.

12. On the various accounts of the "access to justice" principle developed in the domestic context, see e.g. Trevor CW Farrow, Civil Justice, Privatization and Democracy (Toronto: University of Toronto Press, 2014) at 13-17; Trevor CW Farrow, "What Is Access to Justice?" (2014) 51:3 Osgoode Hall LJ 957 at 959-65 [Farrow, "Access to Justice"]; Lori Hausegger, Matthew Hennigar \& Troy Riddell, Canadian Courts: Law, Politics and Process, 2nd ed (Don Mills: Oxford University Press, 2015) at 67-72. 
principle, ${ }^{13}$ there are some serious conceptual difficulties with drawing a parallel between the contemporary domestic conception of access to justice ${ }^{14}$ and its global extension which Necessity de facto suggests. First, this parallel raises deep questions about the role and function of domestic judicial authority in its dealing with private international law cases, ${ }^{15}$ and what a conceptual shift from the "domestic" to the "international" level entails. Is there a distinction between the judge's functioning when dealing with a "purely" domestic case, as opposed to dealing with a "private international law" case? If such a distinction exists, the unexplained move of the "access to justice" principle from its original domestic context towards the international arena is puzzling. Similarly to the serious objections that have been raised with respect to the possibility of extending states' domestic duty to address the challenges of poverty within domestic society to a global level, ${ }^{16}$ Necessity needs to explain a related move from domestic "access to justice" towards its global vision.

Second, Necessity seems to be incompatible with the internal rationale and the normative underpinnings of the Canadian rules of jurisdiction. Within the domestic context, the considerations of "access to justice" apply in a "neutral" way to both sides of the litigation process (the particular defendant and plaintiff), and refer to such matters of the adjudication process as reasonable time for trial, impartial tribunal, ${ }^{17}$ among others. Yet, extended to the context of jurisdiction acquisition, Necessity does something else. By allowing the

13. Black, Pitel \& Sobkin, supra note 5 at 177-85.

14. See e.g. Farrow, "Access to Justice," supra note 12 (mentioning legal needs of Canadians and that "majority of Canadians do not have adequate resources to find legal assistance" at 964-65 [emphasis added]).

15. Perry Dane addresses whether in dealing with private international law cases the functionality of the domestic judicial authority shall be viewed through the prisms of domestic sovereign representatives or as global adjudicators. See Perry Dane, "The Natural Law Challenge to Choice of Law" in Donald Earl Childress, ed, The Role of Ethics in International Law (New York: Cambridge University Press, 2012) 142 at 154, n 29.

16. See e.g. Thomas Pogge, World Poverty and Human Rights: Cosmopolitan Responsibilities and Reforms (Cambridge: Polity Press, 2008).

17. Thus, for example, Necessity has been presented in article 6(1) of the European Convention on Human Rights: "In the determination of his civil rights \& obligations ... everyone is entitled to a fair and public hearing within a reasonable time by an independent and impartial tribunal." See Convention for the Protection of Human Rights and Fundamental Freedoms, 4 November 1950, 213 UNTS 221, art 6(1) (entered into force 3 September 1953). Along similar lines, one of the papers in this Symposium addresses the case of reasonable time of jurisdictional motions, which harms both the plaintiff and the defendant. See Gerard J Kennedy, "Jurisdictional Motions and Access to Justice: An Ontario Tale" (2018) 55:1 Osgoode Hall LJ 79. 
plaintiff to acquire jurisdiction over the defendant in a manner unrelated to the rules of Canadian jurisdiction, the global access to justice of Necessity is questioned from the standpoint of fairness to the defendant and the defendant's reasonable expectations.

The values underlying the jurisdictional rules influence their scope. Thus, one can argue that the value of state sovereignty is embedded, for example, in the abovementioned jurisdictional basis of the present location of the defendant. According to this understanding of the basis of jurisdiction, the sovereign is inherently interested in claiming authority over people who reside within its territory. Another value is fairness to defendants and their reasonable expectations, which are embedded, for example, within the "real and substantial connection" principle, and perhaps also its American "minimum contacts" counterpart. ${ }^{18}$ Under this reading of the "real and substantial connection" principle, the various territorial connecting factors, such as place of contractual performance or place of business, have to be reasonably predicted by the defendant. Finally, the case of the explicit choice basis of jurisdiction seems to crystallize the transnational value of party autonomy under which the parties can (almost) freely choose the identity of the forum to adjudicate their case. ${ }^{19}$

Whatever values underlie jurisdictional rules, and whatever the internal relations are among them, the point here is that the jurisdictional rules seem to be grounded in strong normative reasons. The extension of the domestically developed "access to justice" concept seems to violate serious considerations, such as fairness to the defendant and the idea of state sovereignty. This move should be explained and the violation of the infringed values should be justified on serious grounds. The next section makes some suggestions for such serious grounds.

\section{OBJECTION TWO: INTERNATIONAL CRIMINAL LAW}

Necessity seems to fail to make an important conceptual and practical distinction between private rights, criminal offences, and international criminal acts. The public international law doctrine of "universal jurisdiction" allows nations to prosecute certain human rights violations with little or no connection to the forum state. These offences usually refer to serious cases of human rights violations

18. See International Shoe $v$ Washington, 326 US 310 (1945).

19. Ralf Michaels provides an excellent recent overview of the normative foundations of jurisdictional rules. See Ralf Michaels, "Jurisdiction, Foundations" in Jürgen Basedow et al, eds, Encyclopedia of Private International Law (Northampton, MA: Edward Elgar, 2017) 1043. 
that jeopardize the peace and security of the international community as a whole. Cases of genocide, crimes against humanity, and war crimes are paradigmatic examples of such offences. Presented in these exceptional terms, universal jurisdiction has been preserved as a limited-scope doctrine of international law, primarily developed in the context of international criminal law. ${ }^{20}$ Further, even in this context, the scope and application of universal jurisdiction has been exceptionally limited. An argument against this doctrine is that it trumps the fundamental jurisdictional principles of state sovereignty and territoriality and violates defendants' rights. ${ }^{21}$

The use of universal jurisdiction beyond international criminal law is even rarer and highly debatable. In a few exceptional cases, some systems have incorporated limited explicit legislative provisions that have provided for the possibility of extra-territorial civil actions in relation to international criminal offences. Under the American Alien Tort Statute, ${ }^{22}$ a foreigner may, under limited circumstances, bring a civil action with respect to a tort committed in violation of the law of nations. By the same token, the Canadian Justice for Victims of Terrorism $\mathrm{Act}^{23}$ enables Canadian citizens to seek civil reparation in relation to terrorist activity.

In light of the limited scope of the universal jurisdiction doctrine, its clear connection to international criminal law, and the remarkable scarcity of possible civil actions under this doctrine, the notion of Necessity appears striking. The extension of universal jurisdiction to international private law cases violates the fundamental notions of states' territoriality and sovereignty-notions that are already embedded in the contemporary limited vision of universal jurisdiction. In fact, the treatment of Necessity by Canadian courts seems to have clearly acknowledged this fundamental distinction between private rights

20. See e.g. Ernest A Young, "Universal Jurisdiction, The Alien Tort Statute, and the Transnational Public-Law Litigation after Kiobel' (2015) 64:6 Duke LJ 1023 at 1030-37. Professor Young elaborates on the following key aspects of universal jurisdiction: "universal jurisdiction is unsettled and controversial in principle; its exercise is extremely rare in practice; and when other countries do employ it, it is nearly always a tool of criminal (not civil) enforcement. The governments do not exercise universal jurisdiction even if they have it" (ibid at 1037). See also Mark Chadwick, "Modern Developments in Universal Jurisdiction: Addressing Impunity in Tibet and Beyond" (2009) 9:2 Int'l Crim L Rev 359 at 362-64.

21. Young, supra note 20 at 1042-43.

22. Alien Tort Statute, 28 USC $^{\S} 1350$ (2012) (also referred to as the Alien Tort Claims Act). The Act provides that "the district courts shall have original jurisdiction of any civil action by an alien for a tort only, committed in violation of the law of nations" (ibid).

23. Justice for Victims of Terrorism Act, SC 2012, c 1, s 1. 
and international criminal law. This explains the courts' support of Necessity in relation to civil reparation of plaintiffs tortured by defendants in Iran, ${ }^{24}$ under such exceptional circumstances as "risk of serious physical danger," ${ }^{25}$ and the courts' clear unwillingness to extend Necessity to circumstances where the plaintiff is financially unable to initiate proceedings. ${ }^{26}$ These observations give rise to an argument that would unequivocally challenge the operation of Necessity in the context of private law enforcement and civil actions, where there is no direct relation to any activity that would be regarded as an offence under international criminal law. Civil reparation provisions in international criminal law seem to be of an exceptional character, reserved for serious cases of human rights violations which are to be determined as such by the legislative authorities of particular states. Indeed, the point about the link between Necessity and massive human rights violations has been rightly acknowledged in the literature. ${ }^{27}$

The abovementioned comments on the division between private and criminal laws and the very high threshold of international criminal wrongs needed for jurisdiction acquisition serve as a basis for possible objection to Michael Sobkin's proposal in this volume/in this Symposium to extend Necessity to cases where the foreign system denies the equal status of the litigating parties. While this proposal acknowledges that Necessity cannot simply be grounded on the inability of foreign courts to hear a given court decision, ${ }^{28}$ it seems to make an exception in the case of discrimination within a foreign system or, in Sobkin's words, in the case of a foreign system "where the plaintiff would be denied access to the courts because of his or her ethnicity or religion." ${ }^{29}$ One can, however, challenge this suggestion. The centrality of the non-discrimination principle within private international law should not be underestimated. Yet, an important distinction should be kept in mind: While the equal status of litigating parties has traditionally played a central role as a shield in private international law to exclude the operation of

24. Bouzari v Bahremani, [2011] OJ No 5009 (QL) (ONSC). See also West Van Inc v Daisley, 2014 ONCA 232, 119 OR (3d) 481 (mentioning that Necessity has been designed "for cases like Bouzari" at para 40).

25. Lamborghini, supra note 10 at para 44.

26. Ibid at para 48 .

27. Sobkin, supra note 7 at 217 . This indeed suggests that the scope of Necessity (if anything) should be limited to extreme cases of jurisdiction acquisition within the international context, rather than within the Canadian interprovincial context. While the Canadian jurisprudence generally does not distinguish between interprovincial and international cases, the exceptionally radical vision of Necessity suggests that it would be unlikely to be invoked in the Canadian interprovincial context.

28. Ibid at 209.

29. Ibid at 210 . 
foreign law, foreign jurisdiction, and enforcement of foreign judgements, ${ }^{30}$ this principle has not served as an independent basis for primary private international law rules. It is one thing to disqualify the jurisdiction of a foreign forum based on the non-discrimination principle once the jurisdiction has already been granted, but it is another thing to offer the non-discrimination principle as an independent ground for initial jurisdiction acquisition. The paradigmatic private international law considerations of states' sovereignty and states' equality, ${ }^{31}$ the general civil conception of discrimination law within the internal hierarchy of international human rights, ${ }^{32}$ and the inherently criminal nature of universal jurisdiction all run against the recognition of non-discrimination law as an independent basis for jurisdiction acquisition. In other words, the "shields" should not be confused with the "swords." 33

\section{OBJECTION THREE: “NECESSARY AND PROPER PARTY” AND JOSEPHSON}

One of the most troubling by-products of Morguards Revolution and the introduction of the "real and substantial connection" principle as an organizing

30. For recent discussion of the centrality of the non-discrimination principle as a general disqualification doctrine for the operation of private international law rules, concepts, principles, and doctrines, see Sagi Peari, "Can Better Law Be Married with Corrective Justice of Evil Laws?" (2016) 61:3 McGill LJ 511 at 537-59 [Peari, "Corrective Justice"].

31. For a discussion of the centrality of these considerations within private international law, see ibid at 537-41.

32. On the relatively low status of discrimination law, as compared to international criminal offences, see generally Deborah Hellmann \& Sophia Moreau, eds, Philosophical Foundations of Discrimination Law (Oxford: Oxford University Press, 2013); Jeremy Waldron, "Human Rights: A Critique of the Raz/Rawls Approach" (New York University School of Law, Public Law Research Paper No 13-32, 2013), online: <ssrn.com/abstract=2272745>.

33. Interestingly however, Sobkin seems to acknowledge in his paper this paradigmatic distinction within private international law between "swords" and "shields." Thus, in his discussion on the relation between Necessity and the forum non conveniens doctrine, he seems to acknowledge the difference between the fundamental step of initial acquisition of jurisdiction and the discretion to decline jurisdiction of the already acquired jurisdiction. In contrast to Necessity (where jurisdiction is requested to be granted), under the doctrine of forum non conveniens the jurisdiction has already been acquired and the limited evaluation of the quality of foreign systems/foreign processes works as a shield against foreign jurisdiction disqualification. See Sobkin, supra note 7 at 211 . See also Black, Pitel \& Sobkin, supra note 5 at $162-70$. 
principle of judicial jurisdiction ${ }^{34}$ has been an elimination of the traditional "necessary or proper party" ground of jurisdiction acquisition, which existed under the common law ex-juris rules. ${ }^{35}$ Under traditional common law rules, the plaintiff could acquire jurisdiction based on the institutional considerations of the unification of various proceedings. Under these considerations, cases involving massive air crashes, multiple litigating parties, and contributory negligence are paradigmatic examples of cases that are bound by a common thread, which has itself established an independent ground of jurisdiction. Yet, Morguards Revolution has claimed doctrinal purity of the "real and substantial connection" principle. Accordingly, while leaving the case of party autonomy (i.e., the case of explicit choice of the forum) untouched, the Revolution has eliminated the "proper party" institutional basis of jurisdiction as being inconsistent with the organizing principle of a "real and substantial connection."

This development is unfortunate. Without delving into the normative structure of the jurisdictional rules that would inherently integrate the institutional notion of "proper party," ${ }^{6}$ efficiency considerations seem to essentially require these "common thread" cases to be adjudicated within a single forum. The public institutional considerations of efficiency of proceedings and the convenience of the parties discourage the phenomenon of parallel proceedings and support a rehabilitation of this important category of jurisdiction acquisition. ${ }^{37}$

34. Morguard Investments Ltd v De Savoye, [1990] 3 SCR 1077, 76 DLR (4th) 256. On Morguard's "real and substantial connection" Revolution, see e.g. Joost Blom \& Elizabeth Edinger, "The Chimera of the Real and Substantial Connection Test" (2005) 38:2 UBC L Rev 373.

35. See e.g. Stephen GA Pitel \& Nicholas S Rafferty, Conflict of Laws (Toronto: Irwin Law, 2010) at 81-82; Jean-Gabriel Castel \& Janet Walker, Canadian Conflict of Laws (Markham, Ont: LexisNexis Canada, 2005) (loose-leaf revision 6:1), at 11.55-11.56.

36. I made some comments in this direction in my forthcoming book. See Sagi Peari, The Foundation of Choice of Law: Choice and Equality (New York: Oxford University Press, 2018) at 192-200.

37. Elsewhere, I took this point further and suggested that cases of mass torts, antitrust, aerial disasters, and distribution of workers' compensation, all of a strictly public nature, seem too remote from the underlying rationales of the traditional private international law doctrines and therefore should be treated conceptually differently. See Peari, "Corrective Justice," supra note 30 at 533-35. 
The majority decision in the recent Lapointe decision of the Supreme Court of Canada indeed seems to be an encouraging step in this direction. ${ }^{38}$

One can, however, disagree with the position that Necessity should serve as an appropriate vehicle for the rehabilitation of the traditional common law "necessary and proper party" jurisdictional category ("Proper Party.") ${ }^{39}$ While it is very likely that institutional considerations indeed require a re-establishment of this category, using Necessity for those purposes seems to be a wrong means of achieving a desirable goal. Apparently, Necessity's underlying rationale of global access to justice has nothing to do with the institutional considerations of the Proper Party category. Incorporating the notion of global access to justice into Canadian jurisprudence and challenging the essentials of universal criminal jurisdiction seems to be too high a price to pay for this desirable goal, comparable to making three right turns, rather than one left. The Proper Party category could have been simply rehabilitated through reform, without the radical Necessity move and an entire reorientation of private international law.

Consider the Josephson decision ${ }^{40}$ (which plays a central role in the most recent treatment of Necessity) both in Michael Sobkin's work as well as in that of other supporters of this doctrine. ${ }^{41}$ Indeed, it is the only decision where the courts have accepted the Necessity argument under the provisions of the CJPTA. ${ }^{42}$ The decision involved third party proceedings against Idaho doctors for negligent treatment of Mr. Josephson. Mr. Josephson and Mr. Clark (both Idaho residents) had been golfing in British Columbia, when Mr. Josephson was badly injured. Mr. Josephson sued Mr. Clark in a BC court for negligent golf cart driving. Mr. Clark was seeking to join Idaho doctors to the $\mathrm{BC}$ litigation as

38. Lapointe Rosenstein Marchand Melançon LLP v Cassels Brock \& Blackwell LLP, 2016 SCC 30, [2016] 1 SCR 851 . The case dealt with the jurisdiction question of a massive litigation involving 150 law firms that were added as third parties to the proceeding. Arguably, in such cases strong institutional considerations exist which accord paramount significance to the efficiency of proceedings, and trump ordinary private international law rules such as the jurisdictional rule of "real and substantial connection" in this particular case. These institutional considerations seem to explain the majority opinion in this case, which had determined Ontario as the sole place of jurisdiction to address the negligence claims against 150 law firms. The majority opinion indeed seems to provide some "hints" that would support this line of reasoning. See ibid at paras 50, 56, 59.

39. Sobkin, supra note 7 ("Allowing a court to act as a forum of necessity in these circumstances [of Proper Party] would address these concerns" at 219).

40. Josephson (Litigation Guardian of) v Balfour Recreation Commission, 2010 BCSC 603, 10 BCLR (5th) 369 [Josephson].

41. Sobkin, supra note 7 at 220; Black, Pitel \& Sobkin, supra note 5 at 172-74.

42. Black, Pitel \& Sobkin, supra note 5 at 172. 
third parties, claiming contributory negligence on their part—which allegedly occurred in an Idaho hospital after Mr. Josephson's injury. The Idaho doctors challenged the jurisdiction of the $\mathrm{BC}$ court, pointing to the weak connection between themselves and the case. ${ }^{43}$

One can delineate two types of considerations in support of Necessity within Justice Loo's reasoning in Josephson and in Sobkin's analysis of this case. One consideration focused on the potential unfairness to Mr. Clark in litigating his third party claim against Idaho doctors in an Idaho court. As the expert witness suggested, procedurally, Mr. Clark would have almost definitely lost his case in Idaho. Mr. Clark made several claims in this direction: (1) he did not have the opportunity to undergo Idaho law's pre-litigation screening panel process as a condition to medical malpractice claims; ${ }^{44}$ (2) Idaho law limited liability for medical malpractice to patient-physician relationships; and (3) because of the presence of the "joint and several liability" doctrine in $\mathrm{BC}$, he would be "on the hook for $100 \%$ of the damages." ${ }^{45}$ Both Justice Loo and Sobkin clearly appeared to be sympathetic towards Mr. Clark's arguments of unfairness, stressing his procedural disadvantage had the third party claim been adjudicated in an Idaho court. ${ }^{46}$

With all due respect, I humbly disagree with this line of reasoning. Indeed, had the case been adjudicated in Idaho, the procedural disadvantages would have been fatal to Mr. Clark's third party proceeding. Yet, because of the centrality of comity, considerations of respect, and tolerance of foreign systems within private international law, procedural disadvantage is simply irrelevant to the jurisdiction acquisition question in a $\mathrm{BC}$ court. These considerations have been crystallized through a wide range of contemporary and traditional private international law rules, principles, doctrines, and concepts, which are fundamentally uninterested in the content of foreign law (whether substantive or procedural) and any potential disadvantage to the litigating parties involved in the laws' application. In this respect, one can mention the following key aspects of private international law: (1) the traditional formal and content-free structure of private international law

43. Indeed, from the perspective of Idaho's doctors, the case had very little or no connection to British Columbia: Mr. Clark, Mr. Josephson, and the doctors were all residents of Idaho, and the alleged doctor's negligent treatment took place in Idaho's hospital as well. See Josephson, supra note 40 at para 39.

44. Ibid at para 72 .

45. Ibid at paras 60, 72, 93 (internal quotations omitted).

46. Ibid at paras 74, 91-96; Sobkin, supra note 7 at 222. 
rules; ${ }^{47}$ (2) the very possibility of applying foreign substantive law in the domestic court alongside domestic procedural law, irrespective of any potential hurdles faced by the litigating parties; ${ }^{48}$ and (3) the doctrine of "juridical advantage." ${ }^{49}$ These are just a few examples of the formal structure of private international law which fundamentally abstracts from the content of foreign law and the fairness considerations involved in their application. Giving consideration to Mr. Clark's potential disadvantages within the Idaho system seems simply to challenge the very foundations of the discipline. The incorporation of procedural disadvantage as a ground for the potential operation of Necessity would mean no less than a complete reorientation of the discipline.

There is another, perhaps stronger, type of consideration that can be found both in Justice Loo's reasoning in Josephson and in Sobkin's comments. These are considerations referring to the Proper Party category, which would conceive the Idaho doctors as the "necessary and proper party" to the proceedings between Mr. Josephson and Mr. Clark. As Justice Loo stated, "in the case at bar, the factual matrix of the third party claims is very closely connected to the claim initiated by Mr. Josephson. The only practical approach is for one court to hear all of the matters relating to the case of Mr. Josephson's injures." ${ }^{50}$ This type of public institutional consideration directs that contributory negligence claims be litigated within a single forum, which would justify the BC jurisdiction of Mr. Clark's third party claim. These types of considerations have nothing to do with the advantages or disadvantages of Idaho procedural law. Indeed, the Proper Party doctrine is not presently part of the law but there is a place, perhaps, for reform that will rehabilitate this traditional common law jurisdictional category. Necessity (or more specifically what its incorporation would conceptually and practically entail) does not seem, however, to be an appropriate means for it. Too much seems to be at stake and we do not want to use a sledgehammer to crack a nut.

47. For discussion of the inherently formal structure of traditional and contemporary private international law rules and principles, see e.g. Sagi Peari, "Better Law as a Better Outcome" (2015) 63:1 Am J Comp L 155 at 159-70.

48. On the choice-of-law question in private international law, see e.g. Pitel \& Rafferty, supra note 35 at 206-24.

49. On the doctrine of "juridical advantage," see e.g. Castel \& Walker, supra note 35 at 13.19-13.21; Pitel \& Rafferty, supra note 35 at 133-34.

50. Josephson, supra note 40 at para 100. See also Sobkin, supra note 7 at 221. 


\section{CONCLUSION}

In the above discussion, I have challenged the very plausibility of the Necessity doctrine within Canadian jurisdiction. My argument is that Necessity signifies an unjustified extension of the domestically developed principle of "access to justice" to a global level and its collapse into the public international law doctrine of "universal jurisdiction." The case of residual jurisdiction over international private law cases and civil actions requires a very high threshold, with clear relation to the topic of international crimes, and execution through specific primary legislation. Further, Necessity does not seem to be the appropriate means for rehabilitating the traditional Proper Party category. The provinces of British Columbia and Nova Scotia ought to have followed the province of Saskatchewan in its refusal to incorporate Necessity within its CJPTA adoption process. The good law today is in Saskatoon, not in Halifax or Victoria. 